APRESENTAÇÃO 


\section{VÁRIAS PERSPECTIVAS SOBRE O ENSINO E A APRENDIZAGEM DA TRADUÇÃO NO PAR LINGUÍSTICO PORTUGUÊS-ESPANHOL (E OUTRAS VÁRIAS)}

O dossiê do número 14 da Revista Caracol é dedicado ao ensino e à aprendizagem da tradução no par linguístico português-espanhol $(\mathrm{PT}<>\mathrm{ES})$.

Ao propô-lo, os organizadores tencionávamos que pudesse traçar um panorama do que estão pesquisando e praticando na docência professores que se dedicam à formação de tradutores nessa combinação linguística, principalmente nas Instituiçóes de Ensino Superior (IES) do Brasil. Esperávamos também receber contribuiçôes de fora do país, ou mesmo de outros espaços e modos em que a formação de tradutores acontece, para além da universidade. Por fim, tínhamos no horizonte que o dossiê favorecesse uma rede de comunicação entre docentes-pesquisadores que refletem sobre suas práticas no ensino da tradução entre o português e o espanhol, em diferentes lugares.

Uma vez concluído o número 14, vemos aquele projeto inicial realizado a contento. $\mathrm{O}$ presente dossiê reúne pesquisadores e professores de tradução das seguintes IES do Brasil: Universidade de Brasília (UnB), Universidade Federal do Rio Grande do Sul (UFRGS), Universidade Federal da Integração Latino-Americana (Unila), Universidade Estadual Paulista "Júlio de Mesquita Filho" de São José do Rio Preto (Unesp-Ibilce), Universidade Federal Fluminense (UFF), Universidade Federal de Ouro 
Preto (UFOP). De fora do país, pudemos contar com contribuiçóes da Universidade de Granada (UGR), Espanha, e da Universidade do Minho (UMinho), Portugal.

Ao longo dos sete artigos do dossiê, a aproximação ao ensino e à aprendizagem da tradução PT $<>E S$ recebe dos autores olhares variados: o leitor terá à mão desde uma proposta de unidade didática impulsionada por resultados de estudos empírico-experimentais de corte cognitivo até aspectos pragmáticos com relevância para a formação de tradutores no par $\mathrm{PT}<>\mathrm{ES}$, evidenciados a partir de um estudo de corpus de tradução literária. Os autores mobilizam instrumentais e abordagens diversificados. Os gêneros textuais envolvidos nos estudos incluem receitas, e-mails, textos jornalísticos, literários e audiovisuais. São focalizados diferentes aspectos da formação de tradutores: desenvolvimento da leitura específica para tradução, ensino de revisão, tratamento de fraseologia e de referentes culturais, atenção a interferências sintáticas e pragmáticas na tradução entre essas línguas próximas.

O primeiro artigo do dossiê, "Abordagem processual e ensino de tradução: uma proposta de unidade didática para o par espanhol-português baseada em rastreamento ocular e registro de teclado de mouse", é de autoria de Gleiton Malta, professor de traduçáo português-espanhol no bacharelado em Tradução da Universidade de Brasília (UnB) e doutor em Estudos da Tradução pela Universidade Federal de Minas Gerais (UFMG).

$\mathrm{O}$ autor apresenta em detalhe a proposta de uma unidade didática (UD) pilotada no bacharelado em Tradução Espanhol da UnB, em anos iniciais, 
junto a 20 estudantes com nível A1/A2 do Quadro Comum Europeu de língua espanhola. A UD se originou de pesquisas sobre aspectos cognitivos do processo de tradução, organizando-se principalmente sobre as fases da tradução definidas por Jakobsen (2002) a partir do registro de movimentos de teclado e mouse em tempo real, que é fornecido pelo programa Translog. Jakobsen distinguiu três fases claramente delimitáveis no processo tradutório: orientaçấo, redação e revisão. Estudos descritivos de processo indicaram que a fase de orientação e a fase revisão são negligenciadas por aprendizes de traduçáo, levando a inferir que "essas fases precisam ser trabalhadas na formação do tradutor", diz Malta. Em pesquisas próprias, o autor havia notado que, mesmo em casos de tempo de revisão mais prolongado por parte de aprendizes, os produtos finais apresentavam "problemas de digitação, ortografia e interpretação, dentre outros, que deveriam, a princípio, ter sido sanados" na fase de revisão. Assim, a UD se propóe como uma intervenção didática que focaliza as fases de orientaçáo e de revisão, organizando-se em etapas representadas pelas três fases do processo de tradução, com inspiração no trabalho gradual que é proposto pelo enfoque por tarefas. Além disso, a intervençáo didática proposta no artigo destaca o papel da leitura nas fases, tendo em vista "a leitura para tradução como algo específico e especializado, segundo Shreve et al. (1993), um tipo especial de leitura, incluindo suas fases de orientaçáo, redaçáo e revisão (Jakobsen, 2002)". Estudos baseados em dados de rastreamento ocular, explica o autor, sinalizaram a diferença entre o leitor comum e o leitor-tradutor, com base nas diferentes fixaçôes e movimentaçôes do olhar 
por sujeitos que leem um texto com finalidades diversas da de traduzilo, evidenciando que a leitura para a tradução exige mais das estruturas cognitivas.

As etapas da UD foram previstas para desenvolvimento em quatro aulas de 90 minutos. Nelas, alternam-se momentos de trabalho autônomo e socializado, com o intuito de desenvolver tanto a metarreflexão quanto competências interpessoais; trabalham-se parâmetros para leitura analítica sistemática, como identificação da tipologia textual, segmentação em unidades de tradução (UTs) de acordo com sua funcionalidade; correlaçáo das UTs com as noçôes de contexto de situação e contexto de cultura da linguística sistêmico-funcional de Halliday e Mathiessen (2014); diferentes registros (formal e informal); estimula-se a discussão objetivando a capacidade de justificar as escolhas tradutórias; procura-se desenvolver um alerta para a complexidade envolvida num processo de tradução. Por fim, são sugeridas formas de avaliação da unidade.

Desse modo, a UD trata de amalgamar, numa aplicação pontual, pesquisas recentes no âmbito do desenvolvimento da competência tradutória, dos estudos processuais e da didática da tradução. O Translog, por exemplo, é introduzido na proposta de UD inclusive como instrumento didático em sala de aula. Assim, na linha da proposta apresentada por Anthony Pym (2009) para o uso de estudos processuais em aulas de prática de tradução, o artigo de Malta sugere uma forma concreta de estabelecer a ponte entre os estudos descritivos orientados ao processamento cognitivo da tradução e o ramo aplicado da formação de tradutores, numa relação que ainda 
permanece mais anunciada (dentro dos estudos processuais), do que efetivamente realizada (no ramo aplicado).

No segundo artigo, Cleci Bevilacqua oferece um panorama da disciplina de Revisão de Textos Traduzidos Espanhol/Português, no contexto do bacharelado em Tradução da Universidade Federal do Rio Grande do Sul, onde atua como docente e pesquisadora. Além do relato das atividades de revisão nessa disciplina da grade curricular da UFRGS, a autora apresenta os princípios e parâmetros que norteiam tais atividades. Seu artigo "Revisão de Textos Traduzidos: uma experiência na formação de tradutores de português-espanhol" representa uma contribuição para o tratamento de um aspecto que vem sendo apontado como insuficientemente atendido na formação de tradutores em geral: o ensino da revisão. Ainda a respeito da relevância desse artigo, vale destacar que a revisão eficaz tem-se revelado como um dos principais diferenciais entre profissionais e novatos em tradução, em diferentes pesquisas do ramo cognitivo dos Estudos da Tradução. Com o foco na formação e atuação de profissionais do texto em diferentes áreas, a autora defende a inclusão de disciplinas de revisão destinadas à preparação de tradutores, considerando o possível desenvolvimento de habilidades e competências, especificamente na revisão de textos traduzidos. Bevilacqua destaca as diferenças na revisão de textos traduzidos, se contrastada à de textos produzidos em língua materna.

Após uma breve explanação acerca do novo projeto pedagógico do Curso de Bacharelado em Letras - Tradução Português-Espanhol da UFRGS, a pesquisadora trata de características do perfil de egressos desse curso, isto é, 
do profisssional a ser formado, no sentido de não apenas se configurar como um tradutor, mas como um verdadeiro profissional do texto também. Para tanto, são apresentadas no artigo, para além das competências de traduçáo em ambas as direçôes: a produção e revisão de textos em língua materna e estrangeira; o gerenciamento e elaboração de projetos terminográficos; a prestação de assessoria linguística; o gerenciamento de projetos de tradução e de terminologia; e a localização de softwares, entre outras atividades. Outro aspecto importante enfatizado por Bevilacqua é a identificação e estabelecimento das fronteiras entre revisão e retradução. São apresentados no texto princípios e parâmetros aplicados à revisão de textos traduzidos, que funcionariam metodologicamente como procedimentos, no processo da revisão textual. Por último, a autora exemplifica a prática de revisão de textos de diferentes gêneros, enumerando as etapas seguidas, nos diferentes textos revisados na disciplina.

Os autores do terceiro artigo, "Aplicaciones a la enseñanza de la traducción del Mínimo paremiológico del portugués”, são a professora Ana María Díaz Ferreiro e o professor José Antonio Sabio Pinilla (da Universidade de Granada), dois académicos de referência na (sub)área da tradução português-espanhol no Estado espanhol.

$\mathrm{O}$ conceito de mínimo paremiológico que dá nome ao artigo com que eles contribuíram para o dossiê diz respeito às unidades fraseológicas (ES paremias; PT adágios, ditados, provérbios) mais conhecidas e utilizadas por uma população dada, quer num determinado espaço geográfico, quer numa comunidade linguística mais alargada. A utilidade na Didática de 
segundas línguas deste tipo de informação - uma forma de conhecimento que os utentes espontâneos interiorizaram "automaticamente" no processo de socialização linguística - resulta evidente, já que a sistematização dele contribui para uma melhor produção de discursos pragmaticamente aceitáveis pelos aprendizes.

Porém, a utilidade do mínimo paremiológico vai muito além do campo da Didática de L2 (da Applied Linguistics no sentido mais estrito que essa etiqueta recebia na tradição anglo-saxônica). Assim, neste artigo os autores debruçam-se sobre uma outra aplicação óbvia deste tipo de análise na abordagem dos problemas recorrentes da tradução de qualquer par de línguas: a procura de "correspondências" no nível fraseológico. No caso das línguas especialmente próximas - como é, com certeza, o caso de português e espanhol - este tipo de dificuldades não raro envolve autênticas "armadilhas" práticas que os estudantes devem aprender a (re)conhecer logo no início da sua formação. Para isso, Díaz Ferreiro e Sabio Pinilla assumem explicitamente as fases do processo de tradução de unidades fraseológicas sugeridas por Gloria Corpas Pastor (2003), bem como o modelo composto de competência tradutória do projeto European Master's in Translation (EMT) da Direção Geral de Tradução da Comissão Europeia (2009) ${ }^{1}$.

Os autores partem dos trabalhos em curso para elaborar um corpus base para o mínimo paremiológico del portugués, que deverá ser publicado na série

1 Lembramos aos leitores que o EMT foi um intento de modelar um padrão comum para os diferentes programas de mestrado em Traduçáo na União Europeia. 
"Mínimo Paremiológico" da Biblioteca fraseológica y paremiológica do Centro Virtual Cervantes. O corpus inclui as variantes diatópicas correspondentes ao português europeu, brasileiro e dos PALOP (Países Africanos de Língua Oficial Portuguesa). No modelo de ficha com que eles trabalham aparecem campos específicos para registrar as correspondências e sinônimos com a língua espanhola. A aplicabilidade destas informaçóes para a formação de tradutores, que parece mais do que evidente, é ilustrada pelos autores no artigo com propostas didáticas em que se utilizam como exemplo textos originais e traduçóes de autores portugueses e brasileiros (como Jorge Amado ou José Saramago), bem como tradutores de reconhecido prestígio (como o saudoso professor Basilio Losada, Prêmio Nacional de Traduçáo na Espanha). É, enfim, um artigo cheio de sugestôes de que os formadores de tradutores no par $\mathrm{PT}<>\mathrm{ES}$ poderão tirar grande proveito, para além de uma promissora apresentação de um projeto cujos resultados haverão de ser extremamente úteis para estudantes e pesquisadores das diferentes disciplinas linguísticas nessa mesma combinação.

No quarto artigo, "Interferência e naturalidade no par portuguêsespanhol: línguas próximas, contraste e ensino”, Bruna Macedo de Oliveira, atualmente professora na Universidade Federal da Integração LatinoAmericana (Unila), apresenta e desenvolve resultados de seu mestrado, realizado na Universidade de São Paulo. Na pesquisa combinaram-se o instrumental da Linguística de Corpus - corpora comparáveis em português e espanhol - com corpus de aprendizes de tradução obtido com o programa Translog, que, como vimos, registra em tempo real movimentos de teclado 
e mouse para estudos empíricos de processo tradutório. Cruzam-se, assim, dados de processo e produto, para discutir interferência e naturalidade no desenvolvimento da competência tradutória no par $\mathrm{PT}<>\mathrm{ES}$ e suas implicaçóes para o ensino-aprendizagem da tradução nessa combinação linguística, a partir do exame do tratamento de construçóes subordinadas temporais e finais na tradução do gênero textual receitas.

Partindo da consideração da possível existência de um tipo especial de interferência nas traduções - da língua estrangeira sobre a língua materna, que Presas (2000) atribuiu a um "efeito hipnótico" do texto-fonte-, Oliveira trabalhou sobre a observação inicial de que as estruturas do espanhol como língua estrangeira não só poderiam definir escolhas de estruturas em português, como também inibir a escolha de outras estruturas tão possíveis quanto naturais, e para desenvolvê-la entendeu a necessidade de corroborar a frequência das construçóes, por meio da coleta e posterior indagação de um corpus de receitas em língua portuguesa, utilizado como corpus de comparação. Além da utilização desse corpus, a autora relata a aplicação de duas tarefas de produção textual em língua portuguesa, uma livre e outra dirigida, junto a um grupo de estudantes voluntários do Curso de Letras em espanhol e português, da Faculdade de Filosofia, Letras e Ciências Humanas da USP. Dentre as conclusôes apontadas, Oliveira destaca a importância do foco constrastivo no funcionamento de ambas as línguas, como auxílio para os estudantes na aprendizagem, na consolidação e no aperfeiçoamento de conhecimentos, tanto sobre a segunda língua 
como sobre a própria língua materna, dada a relevância em considerar a proximidade e distância entre as línguas portuguesa e espanhola.

De Portugal, o dossiê recebeu sua quinta contribuiçáo, de autoria da professora da Universidade do Minho, María Dolores Lerma Sanchis. Seu artigo, "Legendagem e transferência intercultural: investigação e prática docente", examina a tradução de referentes culturais num corpus de legendas em português para filmes espanhóis. A noção de competência cultural ou extralinguística recebe destaque neste esse estudo, que ressalta seu peso no trabalho de tradução. Além disso, os referentes culturais são observados na Tradução Audiovisual (TAV), uma modalidade que vem consquistando espaço crescente tanto na pesquisa quanto nos currículos de tradução, em consonância com a forte presença das tecnologias de informação e comunicação no cotidiano da sociedade atual, como ressalta a autora. Ainda no que se refere às tecnologias de informação, a autora lembra, com relação ao par $\mathrm{PT}<>\mathrm{ES}$, que essas duas línguas estão entre as cinco mais usadas na internet, como apontara Oscar Diaz Fouces (2012).

Para a pesquisa relatada no artigo, Lerma Sanchis valeu-se de um corpus de legendas para o português de Portugal de sete filmes do cineasta espanhol Pedro Almodóvar, que têm homogeneidade de gênero (entre o melodrama e a comédia), propondo-se identificar as técnicas de tradução que foram as preferidas para os elementos culturais (EC). Optou por valer-se de legendas profissionais de DVD para os filmes, todos eles obras que estrearam em salas de cinema potuguesas, e aplica a teoria das normas de Toury (1995), focalizando particularmente as normas linguístico-textuais. Os EC são 
definidos no artigo como aqueles elementos linguisticamente opacos, cuja interpretação não se deduz diretamente de seu significado de dicionário, demandando, para compreensão, um conjunto de conhecimentos compartilhados pelos membros de uma comunidade específica, que por sua vez não coincide necessariamente com a totalidade da comunidade que compartilha uma mesma língua. Os EC podem pertencer a diferentes campos, e a autora identificou 18: nomes próprios, espaços públicos ou edifícios sociais, produçóes ou formas artísticas, alimentação, âmbito taurino, presença de outras línguas, músicas, instituiçôes, educação, festividades, história, meios de comunicação social, habitação, rituais sociais, moda, elementos da natureza, marcas comerciais e âmbito político. Numa tradução, podem causar dificuldades não apenas de compreensão, como de transferência, "seja por não existirem no outro sistema de língua-cultura, seja por adquirirem conotaçóes diferentes no sistema-alvo".

No que se refere às técnicas, Lerma Sanchis distingue seis categorias correspondentes às soluçôes verificadas no corpus, "organizadas num continuum que vai de acordo com a maior aproximação à cultura de origem ou à de chegada”. Após a definição de cada técnica, a autora examina exemplos de ocorrências no corpus, refletindo sobre as razóes de sua utilização em cada caso. Num total de 483 ocorrências de EC, vinculadas aos 18 campos, os resultados de análise mostraram tendências bastante uniformes, com dominância da técnica de repetição, revelando com isso um pendor pela extrangeirizaçáo e pela aproximaçáo do receptor à cultura-fonte, com conservação do referente cultural. Como hipótese 
explicativa, evoca-se a presença da imagem como fator que favorece o uso da técnica de repetição, assim como a presença simultânea da língua original na legendagem: ambas contribuiriam para recuperar o papel do EC, minimizando o risco de que o receptor perca informação.

Ao sugerir aplicaçóes didáticas da pesquisa, a autora ressalta a importância da chamada competência intercultural - ou extralinguística dentro das competências do tradutor profissional, discute o peso atribuído à competência intercultural por diferentes atores no campo da tradução (docentes, tradutores, empregadores), em documentos referentes ao ensino de línguas estrangeiras e no campo dos Estudos da Tradução. Investigações do tipo apresentado no artigo podem funcionar como apoio documental para consulta de estudantes, diz a autora. Para um trabalho em sala de aula, ela sugere uma dinâmica de trabalho colaborativo na legendação de um fragmento de filme com alta densidade de EC, que se organizaria em etapas, finalizadas pelo cotejo das propostas dos aprendizes com legendas feitas por profissionais e até mesmo a apresentação em aula de dados quantitativos resultantes de pesquisas como a do artigo, como forma de enriquecer o aprendizado com estudos descritivos.

As professoras da Unesp de São José do Rio Preto Angélica Karim Garcia Simão e Érika Nogueira de Andrade Stupiello são as autoras do sexto artigo, "Repensando a (in)visibilidade do tradutor de webnotícias: propostas para o contexto de formação acadêmica em tradução". Convém lembrar, antes de mais, que elas são coautoras de um volume recente, o Curso de Tradução Jornalistica. Inglês e espanhol (2017), portanto este trabalho se inscreve numa 
área de pesquisa pessoal mais ampla, em que as diversas manifestações da comunicação social e a didática da tradução se encontram.

"Repensando a (in)visibilidade" parte de constatar um fato evidente: as novas tecnologias fizeram com que os fluxos de comunicação circulem por novos meios para chegar até utentes que possuem um perfil muito diferente do tradicional (uns e outros, meios e utentes). Os processos de elaboração das notícias envolvem agora processos de (re)escrita continuada, como as autoras apontam, que são consequência de uma pressão constante dos meios digitais, forçados a lidar com a urgência da transmissão imediata de informaçóes. Essa pressão também tem a ver, claro, com a necessidade de atingir utentes de diferentes espaços culturais a partir de fontes que, náo raro, são estritamente monolíngues. $\mathrm{O}$ espaço profissional da mediação linguística ganha aqui uma dimensão nova, em que o conceito tradicional de fidelidade apenas faz sentido em termos de autêntica (re)apresentação, ou então de reacondicionamento da notícia para novos públicos, como lembram Simão e Stupiello, a partir da perspetiva sugerida por Bielsa e Bassnett (2009). Portanto, esse seria o elemento fulcral que deve ser desenvolvido no processo que tem de conduzir ao desenvolvimento da chamada competência tradutória, nos termos das definiçóes sugeridas pela professora Amparo Hurtado e pelo grupo Pacte da Universidade Autônoma de Barcelona, em diversos trabalhos nos últimos anos, e que já é mainstream no campo.

A partir desses elementos, bem como de uma aplicação da categoria de estratégias de tradução (também a partir do modelo desenvolvido por Hurtado, filtrada por Guerrero 2006), Simão e Stupiello lançam alguns 
alicerces para argumentar uma didática da tradução jornalística ES>PT. Utilizam para isso diversos exemplos de fontes bem reconhecidas (a Agencia Efe ou o jornal El País), que analisam assumindo a tipologia de intervenções mais comuns na tradução de notícias de Bielsa e Bassnett, que tem a ver essencialmente com mudanças, adição, eliminação ou resumo das informaçóes. Todas estas práticas irão ajudar a configurar o novo quadro que terá de agir como pano de fundo para que o (novo) leitor consiga processar adequadamente as informaçóes que os textos jornalísticos contêm.

Com certeza, o caminho que este trabalho abre para o par ES $<>\mathrm{PT}$ poderá ser transitado no futuro com muito proveito, mesmo com "temperos" adicionais, como a análise crítica - portanto em termos ideológicos - dos materiais textuais a partir das fontes. No caso do El País e da Agencia Efe eles são muito evidentes, aliás. A metáfora dos gatekeepers, largamente reconhecida nos estudos sobre a Comunicação e que já tem alguma vitalidade nos Estudos de Tradução, poderia ser um interessante ponto de partida. As sugestóes didáticas que o artigo pode inspirar ultrapassam, portanto, a simples dimensão textual-estrutural, no sentido mais comum.

O sétimo artigo do dossiê, "Las decisiones del traductor y la expresión de foco en dos traducciones al español de un cuento brasileño", é de autoria de Paulo Antonio Pinheiro Correa, professor de Língua Espanhola na Universidade Federal Fluminense (UFF), com doutorado pela Universidade Federal do Rio de Janeiro (UFRJ), e pós-doutorado na Complutense de Madri. O autor se vale de um estudo de caso de tradução literária para realizar uma análise comparada da realização da função pragmatica 
"foco" em relação à ordem dos constituintes sintáticos na oração em duas traduçôes do mesmo conto.

A ordem das palavras na oração foi tradicionalmente considerada questão de estilo e, por isso, em boa medida, acabou sendo deixada de lado na análise gramatical, é o que começa apontando o artigo. Com a noçáo de funçáo pragmática ou informativa, introduzida por Mathesius (1929), precursor da Escola de Praga, e seu desenvolvimento subsequente por outros autores, os estudos contemporâneos têm tornado claro que a ordem dos constituintes é influenciada pela pragmática, apresentando regularidades discursivas vinculadas a parâmetros como os de informação dada $v$ s. informação nova. Contemporaneamente, a relação que há entre a ordem de palavras e questóes informativas vem sendo descrita, também para a língua espanhola, em relação ao conceito de "foco informativo", um termo inicialmente proposto por Halliday (1976). No quadro da Gramática Funcional Holandesa, base teórica principal do artigo, Dik (1997) entende "informação focal" como a informação relativamente mais importante ou relevante numa determinada situaçáo comunicativa, aquela que é considerada pelo falante como essencial para ser integrada na informação pragmática do ouvinte. Na língua espanhola, apresentar uma informação como focal é determinante para sua posição após o verbo na sintaxe, mas também há outros fatores que tornam a questáo mais complexa. A interface entre sintaxe, pragmática e semântica na expressão de foco é observada, no artigo de Pinheiro Correa, num corpus composto por duas traduçóes para o espanhol de um mesmo conto brasileiro. Assim, 
o autor se vale de um estudo de caso de tradução literária para realizar uma análise comparada da realização da função pragmática "foco" em relação à ordem dos constituintes sintáticos na oração.

O corpus utilizado no estudo é composto de duas traduções para o espanhol do conto "O balão fantasma", do escritor brasileiro Rubem Fonseca, uma publicada no México e a outra publicada no Chile, sendo que a chilena se apresenta como uma edição "revisada e adaptada" da mexicana, para publicação no Chile. As traduçóes do corpus foram alinhadas e etiquetadas a partir do instrumental da Linguística de Corpus, e permitiram observar discrepâncias, tanto entre as duas traduçóes para diferentes variedades do espanhol americano, quanto em cotejo com o seu texto original em português brasileiro. As discrepâncias entre as duas traduçóes tornam-se ainda mais reveladoras na medida que representam decisóes especialmente refletidas do tradutor chileno sobre quais intervençóes seriam necessárias na tradução mexicana para adaptá-la para os leitores do Chile. A análise vai mostrando, a partir das decisóes divergentes por parte dos diferentes tradutores, como a interação entre sintaxe e pragmática na a expressão de foco é permeada por determinaçóes complexas, para além da posição pós-verbal da informação focal, envolvendo também as realizaçôes diferentes que a expressão de foco pode ter de acordo com variedades do espanhol ou com recursos do texto literário, em que pode haver configuraçóes próprias do gênero destinadas a oferecer ao leitor "um conhecimento da consciência do narrador", conforme descrito por Soto e Castro (2007), para o espanhol chileno. No cotejo com o conto em português brasileiro, a análise evidencia 
as diferenças no funcionamento da interface sintaxe-pragmática entre o português e o espanhol.

As implicaçôes e aplicaçôes dos fenômenos observados no artigo para a formação em traduçáo PT<>ES são assim explicitadas pelo autor: "podem mostrar ao tradutor brasileiro em formação a enorme quantidade de pressóes discursivas envolvidas na tradução de funçóes pragmáticas".

Para fechar o dossiê do número 14, convidamos José Luiz Vila Real Gonçalves, da Universidade Federal de Outro Preto, a fazer uma resenha crítica do livro Researching Translation Competence by PACTE Group, organizado pela pesquisadora líder do grupo Pacte, Amparo Hurtado, e que foi publicado em 2017 numa das principais coleçóes especializadas em Estudos da Tradução, a Benjamins Translation Library. As pesquisas empírico-experimentais sobre a competência tradutória que vêm sendo realizadas há exatas duas décadas pelo Pacte, na Universidade Autônoma de Barcelona, já se tornaram uma das principais referências no cenário mundial. $\mathrm{O}$ autor da resenha tem se dedicado aos estudos empíricoexperimentais sobre a competência do tradutor e seu desenvolvimento, ao longo dos últimos anos, muitas vezes em diálogo com o grupo Pacte. Assim, pôde oferecer ao leitor do dossiê, mais do que uma resenha: um artigo que examina a obra resenhada em debate com ela, tanto da perspectiva de pesquisas próprias e do grupo em que trabalha, no Brasil, quanto localizando as investigaçóes do Pacte no contexto internacional dos estudos tradutológicos de corte cognitivo, com os quais tem ampla familiaridade. 
Para o número 14 da Caracol tivemos a satisfação de contar também com cinco artigos e três resenhas na seção "vária”. As contribuiçôes dessa seção abrangem estudos tradutológicos, históricos, linguísticos, literários e culturais que, por uma feliz coincidência, em muitos casos mantêm diálogo entre si ou com os próprios artigos do dossiê.

A primeira contribuição faz uma transição entre o dossiê e a vária, posto que também se insere no campo dos Estudos da Tradução: "Tradução audiovisual: estratégias pragmáticas e conversacionais americanas e europeias na legendagem das formas de tratamento nominais". As coautoras são professoras-pesquisadoras de três diferentes IES brasileiras: Leticia Rebollo-Couto (UFRJ), Luisa Perissé Nunes da Silva (UERJ) e Carolina Gomes da Silva (UFPB). No estudo, elas abordam as fórmulas e formas nominais de tratamento na legendagem da animação Inisde Out para duas variedades do português e duas variedades do espanhol. A análise combina perspectivas pragmáticas, sociolinguísticas e conversacionais. Aqui vale lembrar que Leticia Rebollo-Couto é organizadora de uma coletânea de estudos sobre formas de tratamento em português e em espanhol (Rebollo-Couto; Lopes, 2011). O artigo também discute o ideal de "língua neutra" que se instala em estreita relação com produtos de massa, em função de conveniências fundamentalmente mercadológicas, e como as legendas de Inside Out desestabilizam a visão de que possa existir tal variedade "neutra” em uma língua.

A questão da língua neutra em relação com o pan-hispanismo entra em cena também no artigo seguinte, “O Espaço Disciplinar do Espanhol 
(EDE) no Brasil”, de autoria de Edilson da Silva Cruz, professor e diretor de Escola da Rede Municipal de Educação de São Paulo, e Denise Trento Rebello de Souza, professora da Faculdade de Educação da USP. Neste artigo, o "Espaço Disciplinar do Espanhol" é definido pelos autores como a esfera de produção de conhecimentos sobre a língua espanhola em âmbito acadêmico e universitário. O EDE no Brasil é enfocado de uma perspectiva histórica, tendo em vista o conceito de campo de Pierre Bourdieu (1983). Percorre-se esse espaço disciplinar no Brasil desde sua formação, considerando o lugar da língua espanhola em suas relaçóes com a universidade, a escola, a legislação educacional, e chegando até suas mais recentes complexificaçóes, por eventos-chave como o desenvolvimento de linhas de pesquisa voltadas ao funcionamento linguístico, a presença da política linguística pan-hispânica no Brasil, a aprovação da Lei $11.161 / 2005$, a crise da universidade e a reforma do ensino.

O terceiro artigo da vária, "Contribuiçóes da semântica argumentativa para o delineamento da expressão da anterioridade em espanhol", insere-se nos estudos linguísticos e é de autoria de Leandro Silveira de Araújo, professor na Universidade Federal de Uberlância (UFU), doutor pela Unesp de Araraquara, com doutorado-sanduíche na Universidade Autônoma de Madri. O artigo busca subsídios na semântica argumentativa para lançar luzes sobre o funcionamento do pretérito perfecto simple e do perfecto compuesto na língua espanhola. Valendo-se do conceito de Operador Argumentativo (Ducrot, 1989), o autor desenvolve a hipótese de que a seleçáo de uma ou 
outra dessas formas de pretérito de indicativo do espanhol pode definir-se pela direção argumentativa construída em um enunciado.

No artigo "Horacio Quiroga no Brasil: os 'efeitos da língua”, Wilson Alves Bezerra, professor-pesquisador da Universidade Federal de São Carlos (UFSCar) e doutor pela Universidade Estadual do Rio de Janeiro (UERJ), recupera e analisa cartas inéditas trocadas entre Quiroga e Monteiro Lobato. Vemos como Monteiro Lobato foi o principal interlocutor literário de Horácio Quiroga no país, além de ter sido quem introduziu a obra do escritor uruguaio no Brasil. No exame da correspondência entre os dois escritores, situada no contexto da época da Semana de Arte Moderna de São Paulo, considera-se a tensão que havia entre a estética vanguardista e a realista, no debate intelectual daquele momento histórico. Os efeitos do uso do "portunhol" por Quiroga, em suas cartas a Lobato, servem de indício para questionar a crítica literária que leu e valorizou a obra de Quiroga a partir de um duvidoso enquadramento estrito desse escritor uruguaio no ideário da estética realista.

A chave de ouro que encerra a vária é o estudo de corte cultural de autoria de Alfredo Cordiviola, da Universidade Federal de Pernambuco (UFEPE), sobre as "Formas da memória nos queros andinos". O autor faz uma interessante leitura das modificações, ao longo dos séculos, nas formas decorativas dos queros - vasos cerimoniais fabricados desde épocas pré-incaicas na região dos Andes -, elucidando diferentes modos como tais formas foram sendo usadas para evocar os passados andinos. 
Das três resenhas da vária, está ao início também aquela relacionada aos Estudos da Tradução, por seu diálogo mais direto com a temática do dossiê: "A dublagem como modalidade de tradução em um mundo globalizado". Isabella Calafate de Barros e Júlia Chebie Puertas, ambas mestrandas na Universidade Federal do Rio de Janeiro (UFRJ), apresentam o livro Traducción y doblaje: palabras, voces e imágenes, de Rosa Agost, obra publicada em 1999. Depois de quase duas décadas de sua primeira publicação, o livro de Agost já não é encontrado para aquisição a não ser em sebos, mas continua aparecendo como uma das principais e mais completas referências para o estudo da dublagem. Como mostram as autoras da resenha, além de proporcionar uma ótima introdução ao campo mais geral da Tradução Audiovisual (TAV), o livro discute algumas de suas peculiaridades na Espanha, em comparação com outros países, como é o caso da preferência pela dublagem sobre a legendagem, em possível correlação com a maior facilidade que a dublagem teria apresentado para censura, na época da ditadura franquista.

Em “À moda de Cuba”, Wellington Augusto Silva, professor do Colégio Técnico da Universidade Federal Rural do Rio de Janeiro (UFRRJ), resenha uma tradução para o português de um dos primeiros romances do escritor cubano Leonardo Padura, Pasado perfecto (1991): a tradução que foi lançada em novembro de 2016 pela editora Boitempo. Essa tradução, Passado perfeito, foi realizada por Paulina Wacht e Ari Roitman. Na resenha, Silva relembra a boa recepção no Brasil de O homem que amava os cachorros, tradução de romance de Padura, também publicada pela Boitempo, que 
conquistou uma "popularidade surpreendente para uma obra de ficção de 600 páginas”. Na esteira dessa popularidade, a editora trouxe as traduçóes dos quatro primeiros romances de Padura (1991-1998), a tetralogia "Estações Havana”, uma coleção de boas histórias policiais protagonizadas pelo detetive habanero Mario Conde, e da qual Passado perfeito faz parte. O gênero policial, aponta Silva, "encontrou terras férteis em todo o continente americano", compondo "um conhecido veio latino-americano influenciado por essa forma literária”, de que fizeram parte grandes escritores como Bioy Casares, Ricardo Piglia, Roberto Bolaño e, entre os brasileiros, "um extenso séquito formado pelo consagrado Rubem Fonseca”. A esse veio integra-se o Passado perfeito de Padura, no cenário de Havana e à moda de Cuba.

Encerrando as resenhas da vária (e o número 14 da Caracol), Ivan Martucci Forneron, pós-doutorando na Universidade de São Paulo (USP), apresenta o livro de Julia Miranda, Frenética armonía. Vanguardias poéticas latinoamericanas en la Guerra Civil Española, publicado pela casa editorial argentina Beatriz Viterbo, em 2016. Há, na resenha, uma reflexão sobre fissuras, lacunas, fios rotos e desencapados na história oficial em torno da Guerra Civil Espanhola (1936-1939) e da ditadura franquista (1939-1975), uma história escrita como farsa e "mediada pelo terror e o silêncio". Para Forneron, o livro de Julia Miranda oferece mais uma peça das muitas faltantes na recomposição do mosaico dessa história deformada e silenciada, ao mostrar como poetas latino-americanos se inscrevem numa vanguarda poética que produziu um imaginário social orientado pela guerra. Nesse sentido, a vanguarda na poética latino-americana assumiu 
particularidades, na situação cultural da guerra da Espanha. O livro resenhado focaliza a produção poética de seis escritores - Pablo Neruda (Chile), Raúl González Tuñon (Argentina), Vicente Huidobro (Chile), Cayetano Córdova Iturburu (Argentina), Juan L. Ortiz (Argentina) e César Vallejo (Peru) - que "assumiram e viveram a guerra como própria, o que os caracteriza como poetas de dupla nacionalidade", ou imersos em doble territorialidad, nas palavras de Julia Miranda. O título do livro faz referencia ao "Himno a los soldados de la república" (1939) de César Vallejo, que diz, nos versos 63-66 da 4a estrofe: "Proletario que mueres de universo, jen qué frenética armonía | acabará tu grandeza, tu miseria, tu vorágine impelente, | tu violencia metódica, tu caos teórico y práctico, tu gana | dantesca, españolísima, de amar, aunque sea a traición, a tu enemigo!' No livro, o estudo de poemas como o de Vallejo permite ler, na palavra "vanguarda", também um sentido militar de arte de avançar, uma "vanguarda como (r)evolução", que desenhou para a arte do século XX novos imaginários de intervenção social direta.

Os organizadores da Caracol 14 agradecem por todas as submissóes enviadas, não apenas para o dossiê, mas também as que permitiram compor a rica vária deste número. No dossiê, graças à boa resposta às chamadas $\mathrm{e}$ à proposta temática, vemos reunidos pesquisadores dedicados atualmente ao ensino da tradução entre o português e o espanhol e preocupados em refletir sobre a prática de formação de tradutores $\mathrm{PT}<>\mathrm{ES}$, em diferentes instituiçóes de dentro e de fora do Brasil. Nossos sinceros agradecimentos também aos que colaboraram com pareceres para as submissóes do 
número e aos colegas da Área de Espanhol da Universidade de São Paulo, que prestaram apoio na edição dos textos selecionados. Pelo suporte fundamental, agradecemos especialmente à editora-chefe da Caracol, Margareth Santos, e ao trabalho de Fernanda do Nascimento Simóes Lopes e Giuliana Matiuzzi Seerig na monitoria da revista.

\section{Ariel Novodvorski (Universidade Federal de Uberlândia) Heloísa Pezza Cintráo (Universidade de Sáo Paulo) Oscar Diaz Fouces (Universidade de Vigo) \\ Organizadores}

\section{BIBLIOGRAFIA CITADA}

Bielsa, Esperança; Bassnett, Susan. Translation in global news. Londres: Routledge, 2009.

Bourdieu, Pierre. "Algumas propriedades dos campos". In: Questôes de Sociologia. Rio de Janeiro: Marco Zero, 1983.

Corpas Pastor, Gloria (ed.). Diez años de investigación en fraseología: análisis sintáctico-semánticos, contrastivos y traductológicos. Frankfurt am Main: Vervuert, Madrid: Ibero-Americana, 2003.

Diaz Fouces, Oscar. "Algumas consideraçôes sobre a combinação linguística português-espanhol". In: Diaz Fouces, Oscar (ed.). Olhares \& Miradas. Reflexiones sobre la traducción portugués-español y su didáctica. Granada: Atrio, 2012, 119-135.

Dik, Simon. The theory of functional grammar. Complex and derived constructions. Berlin/New York: Mouton de Gruyter, 1997.

Ducrot, Oswald. "Argumentação e topoi argumentativos". In: Guimarães, Eduardo (org.). História e sentido na linguagem. Campinas: Pontes, 1989, 13-38. 
EMT Expert Group (2009). Competences for professional translators, experts in multilingual and multimedia communication. Bruselas: Comisión Europea, 2009. Disponível em: <https://ec.europa.eu/info/sites/info/files/emt competences_translators_en.pdf>. Acesso em 25set. 2017.

Guerrero, Maria José Hernández. "Técnicas específicas de la traducción periodística”. In: Quaderns Revista de Traducció, 13, 2006, 125-139. Disponível em: <http://www.raco.cat/index.php/QuadernsTraduccio/article/ view/51667/55312>.

Halliday, Michael A. K.; Mathiessen, Christian. An introduction to functional grammar. 4. ed. Londres: Routledge, 2014.

Halliday, Michael A. K. "Notes on transitivity and theme in English, part 2". In: Journal of Linguistics, 3-2, 1967, 199-244.

Hurtado Albir, Amparo (ed). Researching translation competence by PACTE group. Amsterdam: John Benjamins, 2017.

Jakobsen, Arnt Lykke. "Translation drafting by professional translators and by translators students". In: Hansen, Gyde (ed.). Empirical Translation Studies. Copenhagen: Samfusdslitteratur, 2002, 191-204.

Mathesius, Vilém. "La structure phonologique du lexique du tcheque moderne". In: Travaux Du Cercle Linguistique de Prague, 1, 1929, 67-84.

Presas, Marisa. "Bilingual competence and translation competence". In: Schäffner, Christina; Adab, Bervely (eds.). Developing translation competence. Amsterdam: John Benjamins, 2000, 19-31.

Pym, Anthony. "Using process studies in translator training. Self-discovery through lousy experiments”. In: Göpferich, Susane; Alves, Fabio; Mees, Inger M. (eds) Methodology, technology and innovation in translation process research. Copenhagen: Samfundslitteratur, 2009, 135-156.

Rebollo-Couto, Leticia; Lopes, Célia Regina dos Santos (orgs.). As formas de tratamento em português e em espanhol: variação, mudança e funçôes conversacionais. Niterói: Editora da UFF, 2011, 497-531. 
Shreve, Gregory M.; Schäffner, Christina; Danks, Joseph. H.; Griffin, Jennifer. "Is there a special kind of reading for translation?: an empirical investigation of reading in the translation process". In: Target, 5-1, 1993, 21-41.

Soto, Guillermo; Castro, Christian. "Sobre los sintagmas nominales preverbales en el español oral y escrito en Chile: gramática y discurso". In: Boletín de Filología XLII, 2007, 341-367.

Stupiello, Érika Nogueira Andrade; Simão, Angélica Karim Garcia. Curso de tradução jornalística: inglês e espanhol. Rio de Janeiro: Transitiva, 2017.

Toury, Gideon. Descriptive Translation Studies and beyond. Amsterdam: John Benjamins, 1995. 